\title{
PERANCANGAN SISTEM INFORMASI PERSEDIAAN BARANG DI KOPERASI BRIMOB POLDA JABAR JATINANGOR
}

\author{
Ririn Marliani \\ STKOM Al Ma'soem \\ marlianiririn@yahoo.com \\ Kuwat Santoso \\ STKOM Al Ma'soem \\ Kuwat.santoso84@gmail.com
}

\begin{abstract}
The need for accurate and fast data processing on Koperasi inventory information system in Brimob Polda Jabar Jatinangor is needed in supporting business processes and reporting. Inventory management is still done manually and has not been done computerized. System design method that is SDLC (System Development Life Cycle) with the system design model used to help facilitate the development of the system, where each stage must be completed first before continuing the next phases. System design tools using Flow Map, Data Flow Diagram, Structure Chart, Data Dictionary and Entity Relationship Diagram.

Koperasi inventory information system in Brimob Polda Jabar Jatinangor implemented with programming languages Microsoft Visual Studio 2010 and Microsoft Access 2010 database.Therefore, information on the supply of cooperative goods in Brimob Polda Jabar Jatinangor expected to assist the Koperasi in processing the data and the process of selling, purchasing, and credit payments.
\end{abstract}

Keywords: Systems, Information, Sales, Purchases, Credit Payments.

\begin{abstract}
ABSTRAK
Kebutuhan pengolahan data yang akurat dan cepat pada sistem informasi persediaan barang koperasi di Brimob Polda Jabar Jatinangor sangat dibutuhkan dalam menunjang proses bisnis dan pelaporan. Manajemen persediaan barang yang dilakukan masih secara manual dan belum dilakukan secara komputerisasi. Metode perancangan sistem yaitu SDLC (System Development Life Cycle) dengan model perancangan sistem menggunakan waterfall yaitu sebuah metode yang digunakan untuk membantu mempermudah pengembangan sistem, dimana setiap tahapan harus diselesaikan terlebih dahulu sebelum meneruskan ketahapan berikutnya. Alat perancangan sistemnya menggunakan Flow Map, Data Flow Diagram, Structure Chart, Kamus Data dan Entity Relationship Diagram.

Sistem informasi persedian barang koperasi di Brimob Polda Jabar Jatinangor diimplementasikan dengan bahasa pemograman Microsoft Visual Studio 2010 dan database Microsoft Access 2010. Dengan demikian informasi persediaan barang koperasi di Brimob Polda Jabar Jatinangor diharapkan dapat membantu pihak koperasi dalam mengolah data penjualan, pembelian, dan pembayaran kredit.
\end{abstract}

Kata Kunci : Sistem, Informasi, Penjualan, Pembelian, Pembayaran Kredit,

\section{PENDAHULUAN}

\subsection{Latar Belakang Masalah}

Kebutuhan informasi merupakan hal yang sangat penting bagi suatu perusahaan atau lembaga dalam keberlangsungan proses bisnisnya. Bahkan dengan seiring pesatnya perkembangan teknologi, khususnya teknologi informasi menjadikan pengolahan informasi 
sebagai ajang kreatifitas dalam peningkatan kinerja, kecepatan dan ketepatan dalam memperoleh informasi dihampir semua bidang. Sistem informasi yang dikemas dengan teknologi berbasis aplikasi program pada komputer ini menjadikan solusi alternatif dalam memecah kebuntuan permasalahan yang dihadapi oleh banyak perusahaan atau lembaga untuk menentukan kebijakan atau informasi yang cepat, akurat dan efektif. Dengan penggunaan secara komputerisasi juga dapat menghasilkan pekerjaan yang dilakukan akan lebih menghemat biaya dan waktu serta akan lebih tepat guna.

Didalam suatu industri atau lembaga yang menangani tentang perdagangan didalamnya terdapat suatu unsur utama yang dinamakan dengan persediaan, Persediaan merupakan unsur yang penting karena persediaan diperoleh, diproduksi dan dijual secara terus menerus untuk kelangsungan hidup suatu instansi perusahaan. Oleh karena itu, instansi perusahaan sering mengalami kesulitan dalam pencatatan dan penilaian persediaan.

Koperasi Primkoppol Brimob Polda Jabar yang beralamat di Jl. Kol. Ahmad Syam No.17 Cikeruh Jatinangor Sumedang merupakan Instansi Pemerintahan yang memiliki unit usaha simpan pinjam dan penjualan barang-barang kebutuhan karyawan Brimob seperti sembako, pakaian, dan barang-barang elektronik dengan anggota koperasi yang terdaftar adalah khusus para anggota Brimob. Dalam proses bisnisnya, sistem pembelian barang kepada supplier dilakukan secara cash dengan sistem pembayaran ditempat atau ditransfer melalui bank. Sedangkan sistem pembayaran barang dari anggota kepada koperasi bisa dilakukan secara cash atau kredit dengan periode waktu tertetu. Adapun sisa pembayarannya dipotong dari gaji dengan sejumlah yang ditagihkan. Dikarenakan semua proses tersebut dilakukan secara manual dan tidak dilakukan secara komputerisasi sehingga menimbulkan beberapa kendala seperti kesulitan dalam mengetahui saldo kredit anggota Di Koperasi, kesulitan mengetahui stok barang, kesulitan mengetahui penjualan dan pembelian setiap hari, riskan terjadinya kesalahan dan kesulitan membuat laporan penjualan, laporan pembayaran kredit, dan laporan pembelian yang masih belum bisa dihasilkan secara otomatis.

Berdasarkan permasalahan tersebut penulis mencoba merancang sebuah sistem informasi yang berbasis komputer dan sistem yang mudah untuk di aplikasikan bagi para staf di Instansi Pemerintahan dengan judul "Perancangan Sistem Informasi Persediaan Barang Di Koperasi Brimob Polda Jabar Jatinangor". Sistem informasi Persediaan ini adalah suatu perangkat lunak yang dapat digunakan untuk mengolah data-data persediaan barang yaitu berupa transaksi penjualan barang, pembayaran kredit dan pembelian barang.

\subsection{Rumusan Masalah}

Rumusan masalah dalam penulisan Tugas Akhir ini meliputi :

1. Perancangan

2. Desain sistem

3. Aplikasi dari sistem persediaan barang

\subsection{Batasan Masalah}

Adapun batasan masalah yang akan dibahas adalah sebagai berikut :

1. Sistem Penjualan Barang

2. Sistem Pembelian Barang

3. Sistem Pembayaran Kredit Anggota

\subsection{Maksud dan Tujuan Penelitian}

Maksud dari sistem yang dibuat oleh penulis adalah untuk membangun sistem informasi persediaan Barang Koperasi di Koperasi Brimob Polda Jabar, serta menyajikan aplikasi komputer yang dapat meningkatkan produktivitas kerja dalam penyelesaian suatu pekerjaan dengan mudah, cepat dan benar. Adapun tujuannya adalah sebagai berikut : 
1. Memudahkan mengetahui saldo kredit anggota di Koperasi

2. Memudahkan mengetahui stok barang

3. Memudahkan mengetahui penjualan dan pembelian setiap hari

4. Menghindari terjadinya kesalahan

5. Memudahkan membuat laporan penjualan, laporan pembayaran kredit, dan laporan pembelian yang masih belum bisa dihasilkan secara otomatis.

\subsection{Kegunaan Penelitian} berikut:

Hasil penelitian ini diharapkan dapat memberikan suatu manfaat atau kegunaan sebagai

1. Bagi AMIK Al Ma'soem

Dapat dijadikan salah satu referensi agar mampu menghasilkan mahasiswa yang terampil dan siap kerjadibidang pekerjaannya masing-masing, sehingga mahasiswa mempunyai kesempatan kerja.

2. Bagi Brimob Polda Jabar

Semoga sistem ini dapat diaplikasikan langsung, sehingga dapat membantu dalam proses perhitunganpersediaan barang koperasi serta penjualan yang di lakukan di koperasi setiap hari.

3. Bagi penulis

Diharapkan dapat menambah pengetahuan dan pengalaman selama melakukan penelitian juga dapatmemanfaatkan ilmu pengetahuan yang diperoleh dan diharapkan dapat menambah ilmu pengetahuan.

4. Bagi Pembaca

Diharapkan hasil penelitian ini dapat bermanfaat untuk dijadikan referensi atau sumber yang dapatdikembangkan agar bisa lebih baik lagi.

\subsection{Tinjauan Pustaka}

\section{Siklus Hidup Pengembangan Sistem}

Proses pengembangan sistem ini melewati beberapa tahapan dari sistem yang direncanakan sampai sistem tersebut diterapkan. Berikut ini digambarkan metode SDLC (System Development Life Cycle) dengan model waterfall dimana metode ini memerlukan beberapa tahapan dan dapat dilihat pada gambar 1 berikut ini.

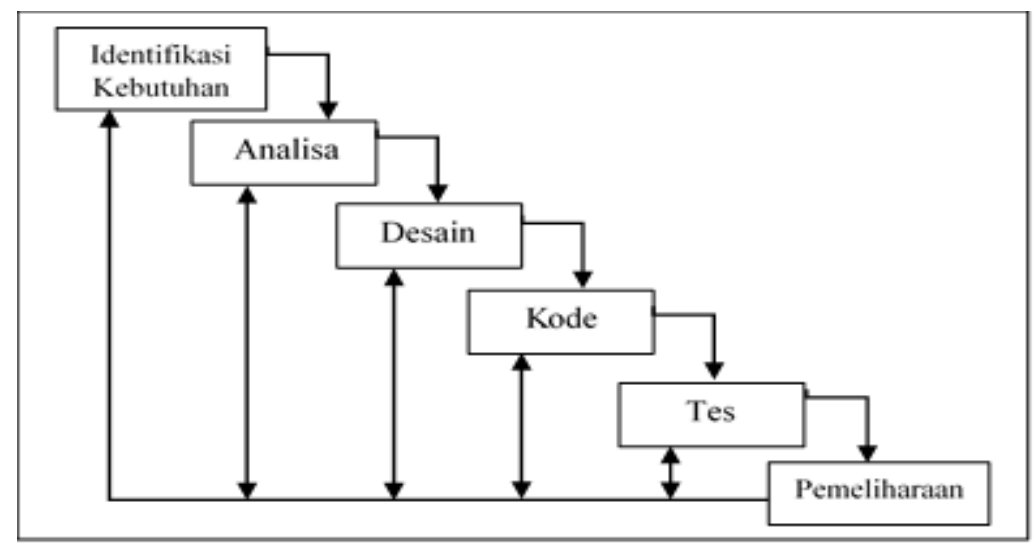

Sumber: Jogianto Hartono (2005: 80)

Gambar 1 Model Waterfall

Penjelasan rinci dari gambar 1 mengenai model waterfall adalah sebagai berikut :

1. Tahap Identifikasi Pemakai 
Pada awalnya pengembangan perangkat lunak didasarkan pada kebutuhan atau permintaan pada suatu sistem.

2. Tahap Analisa

Dari kebutuhan atau permintaan di tahap sebelumnya dilakukan suatu tahap analisan atau kajian yang mendalam untuk hal tersebut, termasuk survey pendahuluan jika dipelukan untuk mengumpulkan data-data yang ada.

3. Tahap Desain

Setelah cukup melakukan analisis, tahap berikutnya ialah perancangan sistem, termasuk pemilihan bahasa yang digunakan.

4. Tahap Kode

Setelah design selesai, dan diterapkannya bahasa yangakan digunakan, maka proses berikutnya pengkodean atau penulisan programnya.

5. Tahap Tes

Diadakannya pengujian terhadap program yang telah dibuat. Semua masalah dan kendala jka muncul akan dibawa ke proses tahap sebelumnya untuk dilakukan kajian lebih lanjut.

6. Tahap Pemeliharaan

Diadakan pemeliharaan terhadap program yang sudah ada. Pemeliharaan meliputi penanggulangan masalah perbaikan pada sistem.

\section{Perangkat Pengembangan Sistem}

Untuk mengkomunikasikan hasil analisa dan rancangan sistem kepada para pemakai dan untuk dapat melakukan langkah-langkah dalam rangka pengembangan sistem yang terstruktur, analisa sistem menggunakan suatu standar untuk mencerminkan aliran data dan dokumen dalam sistem. Hal ini dapat berupa gambar, diagram atau grafik.

\section{Data Flow Diagram}

Data flow diagram merupakan pembuatan pemodelan yang umum digunakan dalam perancangan sebuah aplikasi yang sering digunakan untuk menggambarkan suatu sistem yang telah ada atau sistem yang baru yang akan dikembangkan secara logika tanpa mempertimbangkan lingkungan fisik dimana data tersebut mengalir dan akan disimpan. Adapun pengertian DFD menurut Jogiyanto Hartono (2005:701)yaitu "Diagram yang menggunakan notasi simbol untuk menggambarkan arus data system".

DFD merupakan alat yang digunakan dalam metodologi pengembangan sistem yang terstruktur dan dokumentasi dari sistem yang baik. Adapun simbol-simbol yang digunakan dalam DFD, dapat dilihat pada tabel 1 berikut ini.

Tabel 1 Simbol-Simbol dalam Data Flow Diagram

\begin{tabular}{|l|l|}
\hline \multicolumn{1}{|c|}{ Simbol } & \multicolumn{1}{|c|}{ Keterangan } \\
\hline & $\begin{array}{l}\text { Ekternal Entitas } \\
\text { Merupakan kesatuan (entity) di } \\
\text { lingkungan sistem, dapat berupa } \\
\text { orang, organisasi atausistem } \\
\text { lainnya yang berada di } \\
\text { lingkungan luarnya, yang akan } \\
\text { memberikan input atau menerima } \\
\text { output dari sistem. }\end{array}$ \\
\hline
\end{tabular}




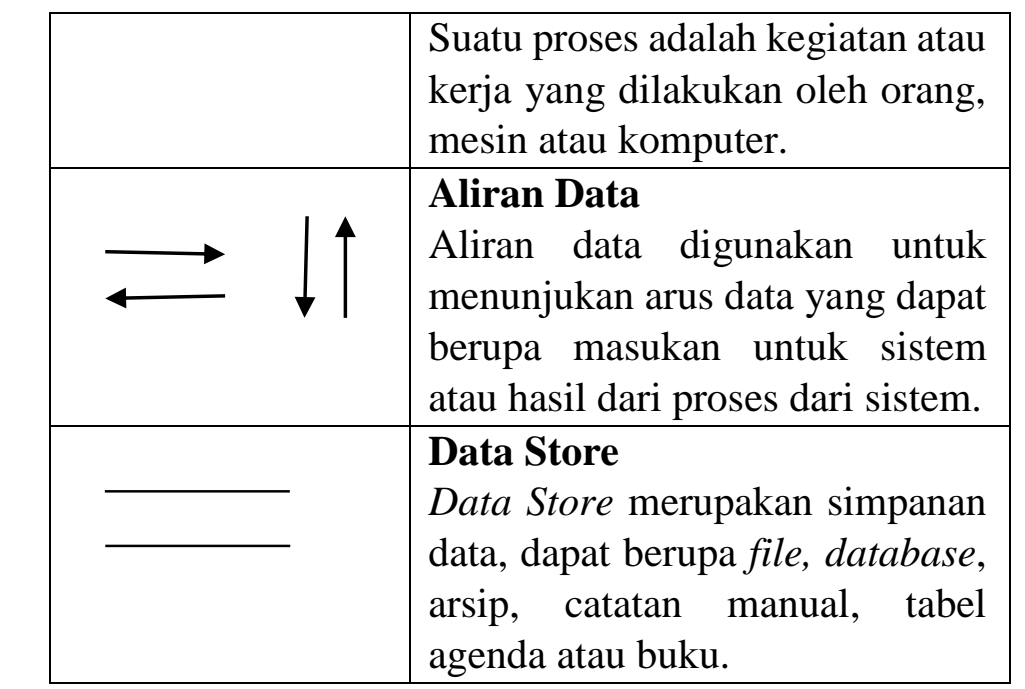

Sumber : Anastasia Diana dan Lilis Setiawati (2011: 40)

\section{Diagram Entity Relationship Diagram (ERD)}

Entity Relationship diagram (ERD) merupakan suatu teknik yang dilakukan oleh para System Analys dalam memodelkan kebutuhan proyeknya yang sebagai persyaratan pengembangan sistem. (Brady dan Loonam, 2010).Diagram ER merupakan diagram yang berisi suatu komponen-komponen himpunan entitas dan himpunan relasi, yang masing-masing dilengkapi dengan atribut yang merepresentasi seluruh fakta. Simbol-simbol yang digunakan dalam diagram ER selanjutnya dapat dilihat pada tabel 2 berikut :

Tabel 2 Simbol-simbol Diagram ER

\begin{tabular}{|c|c|}
\hline Tombol & Keterangan \\
\hline & Entity Set \\
\hline & Relationship Set \\
\hline & Lambang Atribut \\
\hline & $\begin{array}{l}\text { Sebagai penghubung antar } \\
\text { himpunan relasi dengan } \\
\text { himpunan entitas dan } \\
\text { himpunan entitas dengan } \\
\text { atributnya ataulink }\end{array}$ \\
\hline
\end{tabular}

\section{Flow Map}

Flow Map adalah bagan yang menunjukkan aliran atau komunikasi dokumen di dalam program atau prosedursistem secara logika. Bagan luar digunakan terutama untuk alat bantu komunikasi dan dokumentasi. Simbol-simbol yang digunakan dapat dilihat pada tabel 3.

Tabel 3 Simbol Flow Map

\begin{tabular}{|c|l|l|}
\hline Simbol & \multicolumn{1}{|c|}{ Nama } & \multicolumn{1}{c|}{ Keterangan } \\
\hline & Dokumen & $\begin{array}{l}\text { Menunjukan dokumen } \\
\text { input dan output baik } \\
\text { proses manuak, mekanik } \\
\text { atau komputer }\end{array}$ \\
\hline
\end{tabular}




\begin{tabular}{|c|c|c|}
\hline & Proses Manual & $\begin{array}{l}\text { Menunjukan pekerjaan } \\
\text { yang dilakukan secara } \\
\text { manual }\end{array}$ \\
\hline & $\begin{array}{c}\text { Proses } \\
\text { Komputerisasi }\end{array}$ & $\begin{array}{lr}\text { Menunjukan } & \text { kegiatan } \\
\text { proses dari operasi } \\
\text { program komputer }\end{array}$ \\
\hline & File Arsip & $\begin{array}{l}\text { File non komputer yang } \\
\text { diurutkan dan diarsipkan } \\
\text { berdasarkan huruf, angka } \\
\text { maupun tanggal }\end{array}$ \\
\hline & Arus Proses & $\begin{array}{l}\text { Menunjukan arus dari } \\
\text { proses }\end{array}$ \\
\hline & Keputusan & $\begin{array}{ll}\text { Menunjukan pemilihan } \\
\text { kondisi dan pemilihan } \\
\text { keputusan }\end{array}$ \\
\hline & File & $\begin{array}{l}\text { Menunjukan input atau } \\
\text { output menggunakan } \\
\text { hardisk/komputer }\end{array}$ \\
\hline & Konektor & $\begin{array}{l}\text { Menunjukan penghubung } \\
\text { dalam satu halaman }\end{array}$ \\
\hline & Entry Data & $\begin{array}{l}\text { Menunjukan pengisisan } \\
\text { data }\end{array}$ \\
\hline
\end{tabular}

Sumber : Jogiyanto Hartono (2005: 796)

\section{Struktur Chart}

Struktur chart merupakan suatu diagram yang menggambarkan modul program dari sistem informasi yang dibuat untuk mengidentifikasi dan mengilustrasikan organisasi dari digitalisasi dalam bentuk modul dan sub modul. Simbol-simbol dasar dapat dilihat pada tabel 4 berikut ini.

\begin{tabular}{|c|c|}
\hline \multicolumn{2}{|r|}{ Tabel 4 Simbol Struktur Chart } \\
\hline Simbol & Keterangan \\
\hline & $\begin{array}{l}\text { Module } \\
\text { Menunjukan suatu modul }\end{array}$ \\
\hline & $\begin{array}{l}\text { Connection } \\
\text { Digunakan untuk menghubungkan suatu } \\
\text { modul dengan modul lainnya. }\end{array}$ \\
\hline & $\begin{array}{l}\text { Decision } \\
\text { Menentukan suatu penyeleksian kondisi } \\
\text { di dalam modul. }\end{array}$ \\
\hline & $\begin{array}{l}\text { Loop } \\
\text { Menunjukan suatu perulangan didalam } \\
\text { simbol }\end{array}$ \\
\hline $\mathrm{O}-$ & $\begin{array}{l}\text { Elemen Data } \\
\text { Menunjukan suatu data yang } \\
\text { dikirimkan dari suatu modul ke modul } \\
\text { yang lainnya. }\end{array}$ \\
\hline$\theta-$ & Elemen Control \\
\hline
\end{tabular}




\begin{tabular}{|l|l|}
\hline & $\begin{array}{l}\text { Menunjukan suatu elemen control yang } \\
\text { dikirimkan. }\end{array}$ \\
\hline
\end{tabular}

Sumber : Jogiyanto Hartono (2005: 743)

\section{Data Dictionary}

Kamus data adalah katalog fakta tentang data dan kebutuhan-kebutuhan informasi dari suatu sistem informasi. Dengan menggunakan kamus data analisis sistem dapat mendeinisikan data yang mengalir di sisten dengan lengkap . Simbol-simbol yang digunakan dalam kamus data dapat dilihat pada tabel 5 .

Tabel 5 Simbol Kamus Data

\begin{tabular}{|c|l|}
\hline Simbol & \multicolumn{1}{|c|}{ Keterangan } \\
\hline$=$ & Sama dengan satu terdiri dari atau terbentuk dari \\
\hline+ & Simbol dan \\
\hline() & Pilihan boleh atau tidak \\
\hline\{\} & Pengulangan \\
\hline[] & Pemilihan satu objek dari beberapa alternatif \\
\hline$* *$ & Komentar \\
\hline$@$ & Atribut kunci \\
\hline I & $\begin{array}{l}\text { Pemisah dari beberapa alternatif yang } \\
\text { didefinisikan }\end{array}$ \\
\hline
\end{tabular}

Sumber: Jogiyanto Hartono (2005: 730)

\section{METODOLOGI}

\subsection{Metode Penelitian}

Metodologi penelitian yang digunakan penulis adalah metode deskriptif, yaitu melakukan teknik survei pada objek yang diteliti dengan menyelidiki sistem yang ada dengan cara mengumpulkan data, sehingga dapat dipahami masalahnya. Menurut Nazir (1988: 63) bahwa dijelaskan mengenai metode deskriptif yaitu "Metode deskriptif adalah suatu metode dalam meneliti status dan kelompok manusia, suatu objek, suatu set kondisi, suatu sistem pemikiran ataupun suatu peristiwa pada masa sekarang."

Untuk menunjang metode penelitian ini, menurut Sugiyono (2013:224) maka diperlukan :

1. Teknik Wawancara

Merupakan teknik dengan cara pertemuan dengan dua orang yang saling memberikan informasi yang terkait dengan penelitian yang akan dibangun dalam bentuk lisan dan tanya jawab, sehingga dimungkinkan akar permasalahan dan kebutuhan aplikasi lebih valid dan mancapai sasarannya.

2. Teknik Pengamatan/Observasi

Merupakan suatu proses yang kompleks, suatu proses yang tersusun dari berbagai proses biologis dan psikhologis. Dua di antara yang terpenting adalah proses-proses pengamatan dan ingatan.

3. Teknik Dokumentasi

Dokumen adalah berkas atau pencatatan suatu kejadian yang lalu. Dokumen dapat berupa tulisan, rekaman, gambar dan hasil karya seseorang. Dokumen yang berbentuk tulisan misalnya catatan harian, sejarah kehidupan (life histories), ceritera, biografi, peraturan, kebijakan. Dokumen yang berbentuk rekaman misalnya rekaman tape record suara dan video. Dokumen yang berbentuk gambar misalnya foto, gambar hidup, sketsa dan lainlain. Dokumen yang berbentuk karya misalnya karya seni, yang dapat berupa gambar, patung, film dan lain-lain. Studi dokumen merupakan pelengkap dari penggunaan metode observasi dan wawancara dalam penelitian kualitatif. 
4. Teknik Kepustakaan/ Studi Pustaka

Yaitu meneliti dengan cara mengkaji atau dengan cara membaca buku yang ada hubungan dengan masalah yang diteliti untuk membandingkan dengan keadaan sebenarnya

\subsection{Metode Pengembangan Sistem}

Metode yang digunakan penulis dalam penulisan tugas akhir ini adalah metode SDLC (System Development Life Cycle) model Waterfall. Proses pengembangan sistem melewati beberapa tahapan dari sistem yang direncanakan sampai sistem tersebut diterapkan. Model Waterfall yang diingakan dalam tugas akhir ini di mulai dari identifikas pemakai, analisa, desain, kode, test, perawatan.

\section{ANALISIS DAN PERANCANGAN SISTEM}

\subsection{Deskripsi Prosedur Kerja}

Prosedur kerja dari sistem informasi Persediaan Barang di Koperasi Brimob Polda Jabar terdiri atas Pembelian Barang, Penjualan Barang, dan Pembayaran Kredit Anggota. Analisis prosedur kerja ini bertujuan untuk mengidentifikasi serta mengevaluasi kesalahan yang terjadi serta kebutuhan-kebutuhan yang diharapkan sehingga dapat diusulkan perbaikanperbaikannya. Berikut prosedur kerja di Koperasi Brimob Polda Jabar Jatinangor :

1. Prosedur Pembelian Barang

a. Supplier memberikan faktur beli sebanyak tiga rangkap dan memberikannya kepada bagian gudang untuk pengecekan barang.

b. Jika barang tidak sesuai, maka faktur beli dan barang akan di kembalikan kepada supplier. Jika sesuai faktur beli maka di tanda tangan dan di serahkan kepada bagian admin.

c. Faktur beli yang telah di tanda tangani diinput oleh admin.

d. Bagian admin menginput faktur beli sesuai yang telah di tanda tangan oleh bagian gudang dengan mengakses file barang dan menyimpannya di file beli.

e. Bagian admin mencetak bukti pembelian barang sebanyak 3 rangkap dan mencetak laporan pembelian untuk diserahkan kepada bendahara koperasi.

f. Bukti pembelian barang dan laporan pembelian diserahkan oleh bendahara untuk di berikan kepada ketua koperasi.

g. Ketua koperasi menandatangani bukti pembelian barang dan laporan pembelian , rangkap satu di arsipkan, rangkap 2 di berikan kepada bendahara, dan rangkap 3 di berikan kepada bagian admin. 


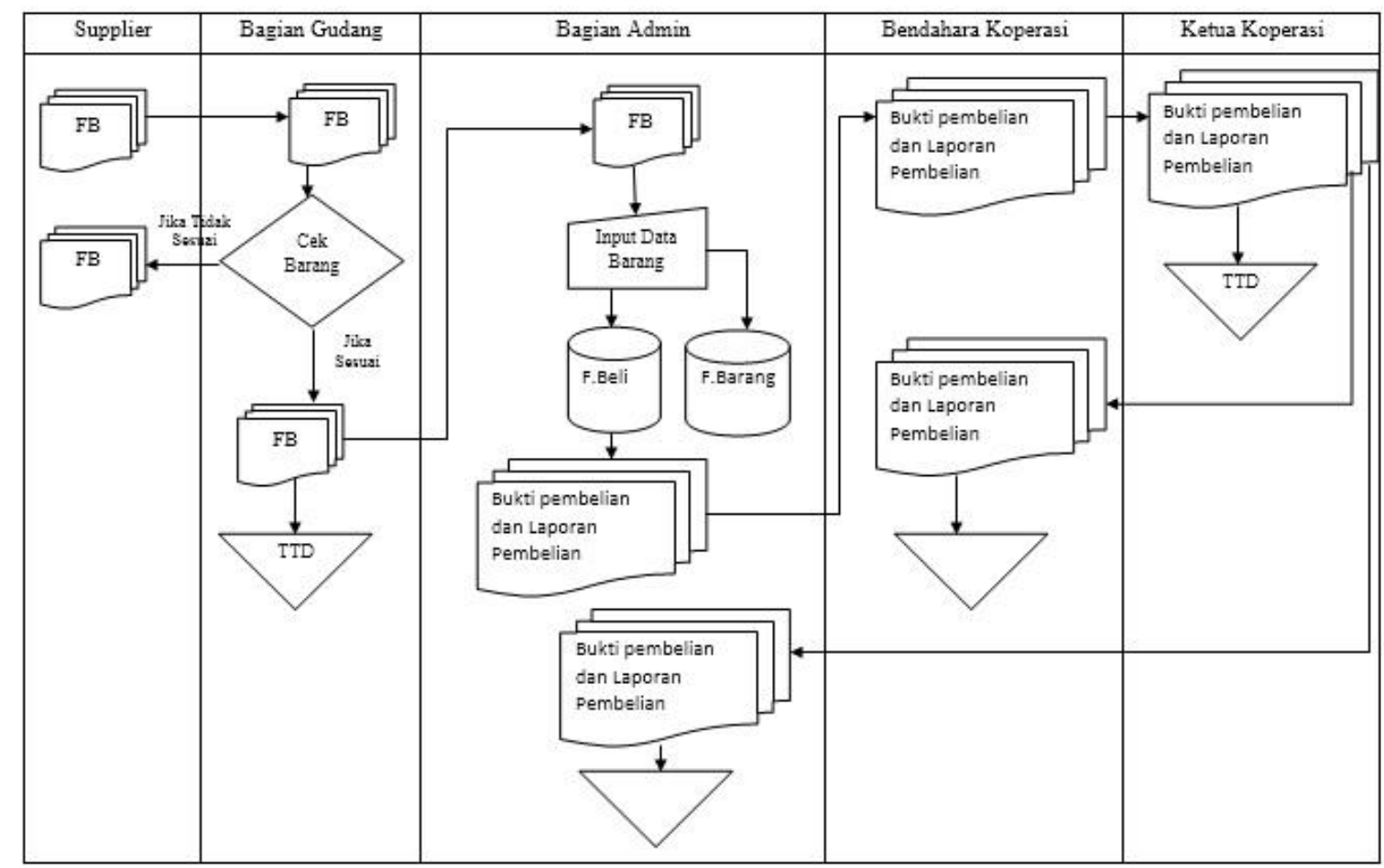

Sumber : Hasil Penelitian

Gambar 2 Flowmap Pembelian Barang

2. Prosedur Penjualan Barang

a. Bagian penjualan menyerahkan data anggota ke bagian admin untuk di input dan menyimpannya di file anggota.

b. Bagian penjualan meyerahkan daftar belanja anggota ke bagian admin untuk di input.

c. Bagian penjualan menanyakan kepada anggota akan membeli barang secara tunai atau kredit. Jika kredit maka diberikan nota kredit, jika membeli barang secara tunai maka akan diberikan nota lunas.

d. Nota tersebut di input oleh admin dan di simpan di file kredit (bila pembayaran kredit), dan file penjualan (bila pembayaran tunai).

e. Dari file barang dan file penjualan dihasilkan laporan penjualan yang di cetak sebanyak dua rangkap yang diberikan kepada bendahara koperasi.

f. Bendahara koperasi memberikan kepada ketua koperasi untuk di tanda tangan dan di arsipkan.

g. Ketua koperasi menandatangani laporan penjualan dan mengarsipkannya. Rangkap satu diarsipkan oleh ketua koperasi, rangkap dua di berikan kepada bendahara kemudian diarsipkan. 


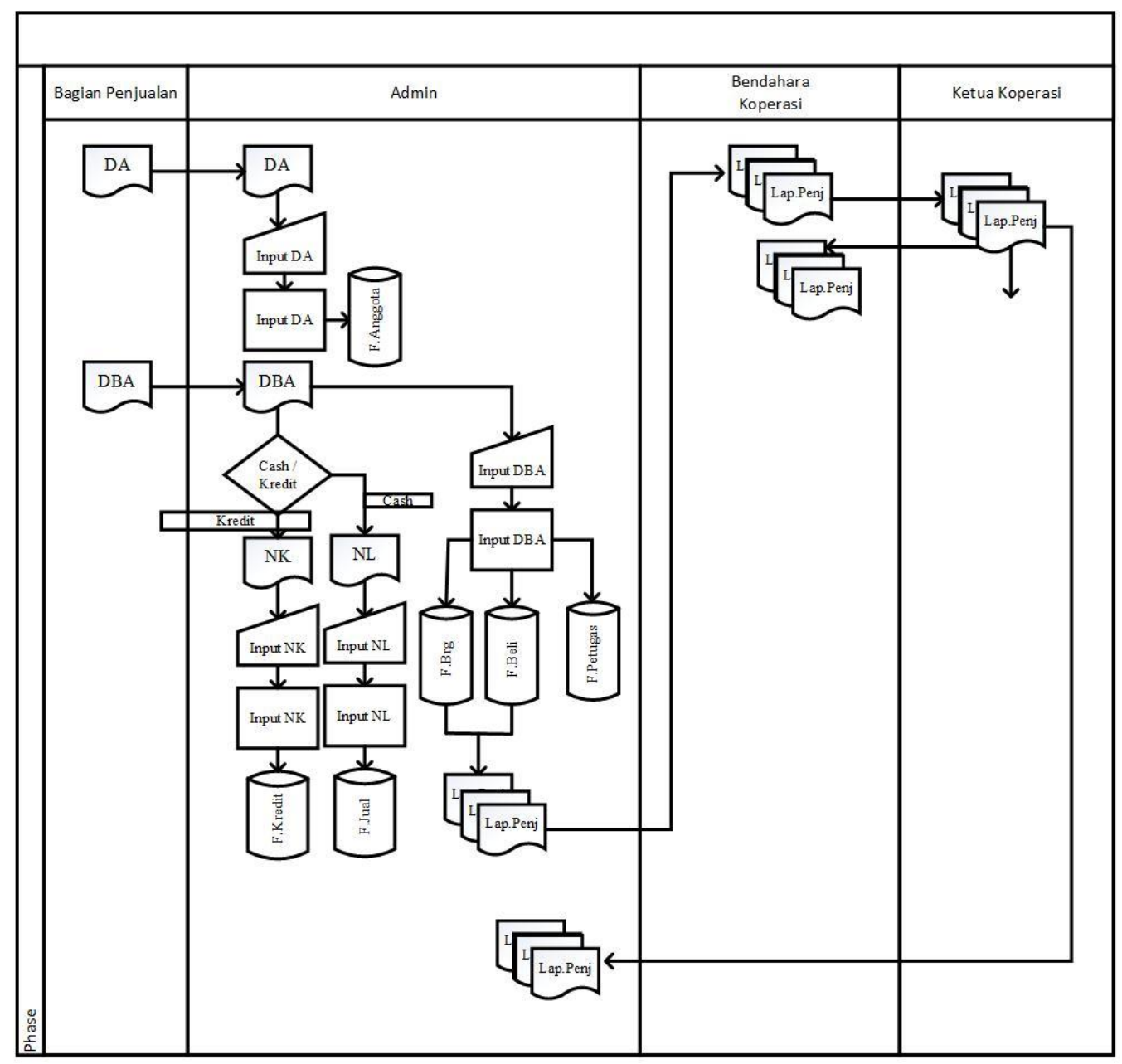

Gambar 3 Flowmap Penjualan Barang

3. Prosedur Pembayaran Kredit Anggota

a. Bendahara koeprasi membuat DPKA (Dokumen Penagihan Kredit Anggota) kepada juru bayar.

b. Juru bayar memberikan DPAK ke bagian admin dan keuangan untuk di input.

c. Admin menginput DPAK dan menyimpannya di file kredit.

d. Bagian keuangan pusat melakukan pemotongan gaji sebesar yang tertagih di tambah jasa $3 \%$ pada anggota yang bersangkutan. 
e. Bagian keuangan pusat memberikan BDPPG (Bukti Daftar Pengajuan Pemotongan Gaji) yang di berikan kepada admin untuk di input, dan bukti pemotongan gaji anggota kepada yang bersangkutan.

f. Admin menginput BDPPG dengan mengakses file kredit dan file anggota yang menghasilkan Laporan Pembayaran Kredit Anggota di berikan kepada bendahara koperasi.

g. Bendahara memberikan Laporan Pembayaran Kredit Anggota diberikan kepada ketua koperasi.

h. Ketua koperasi menandatangani laporan pembayaran kredit anggota dan di arsipkan.

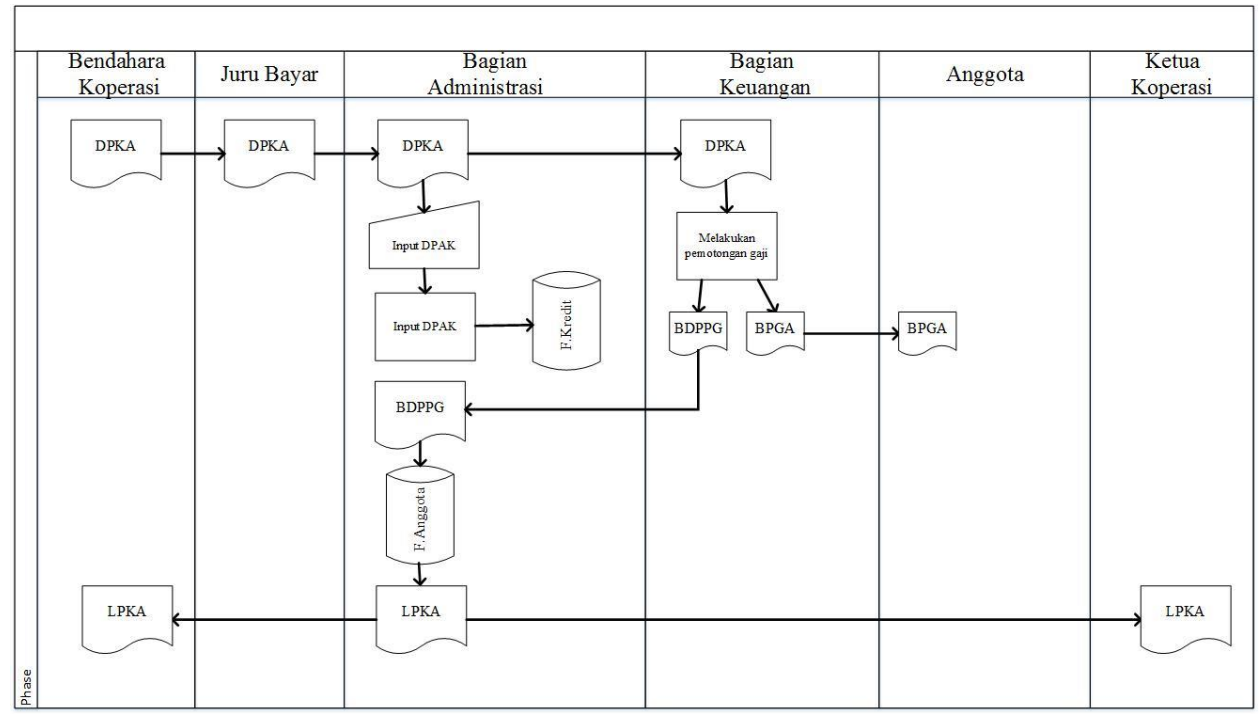

Sumber : Hasil Penelitian

Gambar 4 Flowmap Pembayaran Kredit Anggota

\subsection{Deskripsi Dokumen}

Dokumen adalah setiap proses pembuktian yang didasarkan aras jenis sumber apapun, baik itu yang bersifat tulisan, lisan, gambaran, atau arkeologis. Berikut dokumen-dokumen yang terdapat dalam perancangan sistem ini.

1. Data Anggota

Fungsi : Untuk megetahui informasi detail anggota

Sumber : Koperasi Brimob Polda Jabar

Distribusi : Wakil Ketua Primkoppol

Attribut : NoAnggota, NamaAnggota, Bagian,

NoTelepon,TglMasuk, Status

2. Data Barang

Fungsi : Untuk mengetahui detail barang

Sumber : Koperasi Brimob Polda Jabar

Distribusi : Bendahara Koperasi

Attribut :KodeBrg, NamaBrg, Stock, StockMin,

HargaJual, HargaBeli, Satuan

3. Data Supplier

Fungsi : Untuk mengetahui detail supplier

Sumber : Koperasi Brimob Polda Jabar

Distribusi : Bendahara Koperasi

Attribut : NoSupp, NamaSupp, Alamat, NoBank,

NamaBank, NoRek 
4. Data Penjualan

Fungsi : Untuk mengetahui detail penjualan

Sumber : Koperasi Brimob Polda Jabar

Distribusi : Bendahara Koperasi

Attribut : NoJual, KodeBrg, Qty, JmlJual,

LabaKotor

5. Data Pembelian

Fungsi : Untuk mengetahui detail pembelian

Sumber : Koperasi Brimob Polda Jabar

Distribusi : Bendahara Koperasi

Attribut : NoBeli, KodeBrg, Qty, JmlBeli

\subsection{Skema Relasi Basis Data}

Perangkat lunak merupakan suatu sistem aplikasi yang berkaitan dengan pengolahan data yang akan dipakai oleh sistem tergantung kepada perangkat lunak yang akan digunakan.Daftar basis data atau database dari program Sistem Informasi Persediaan Barang Koperasi Brimob Polda Jabar Jatinangor dapat dilihat pada gambar dibawah ini.

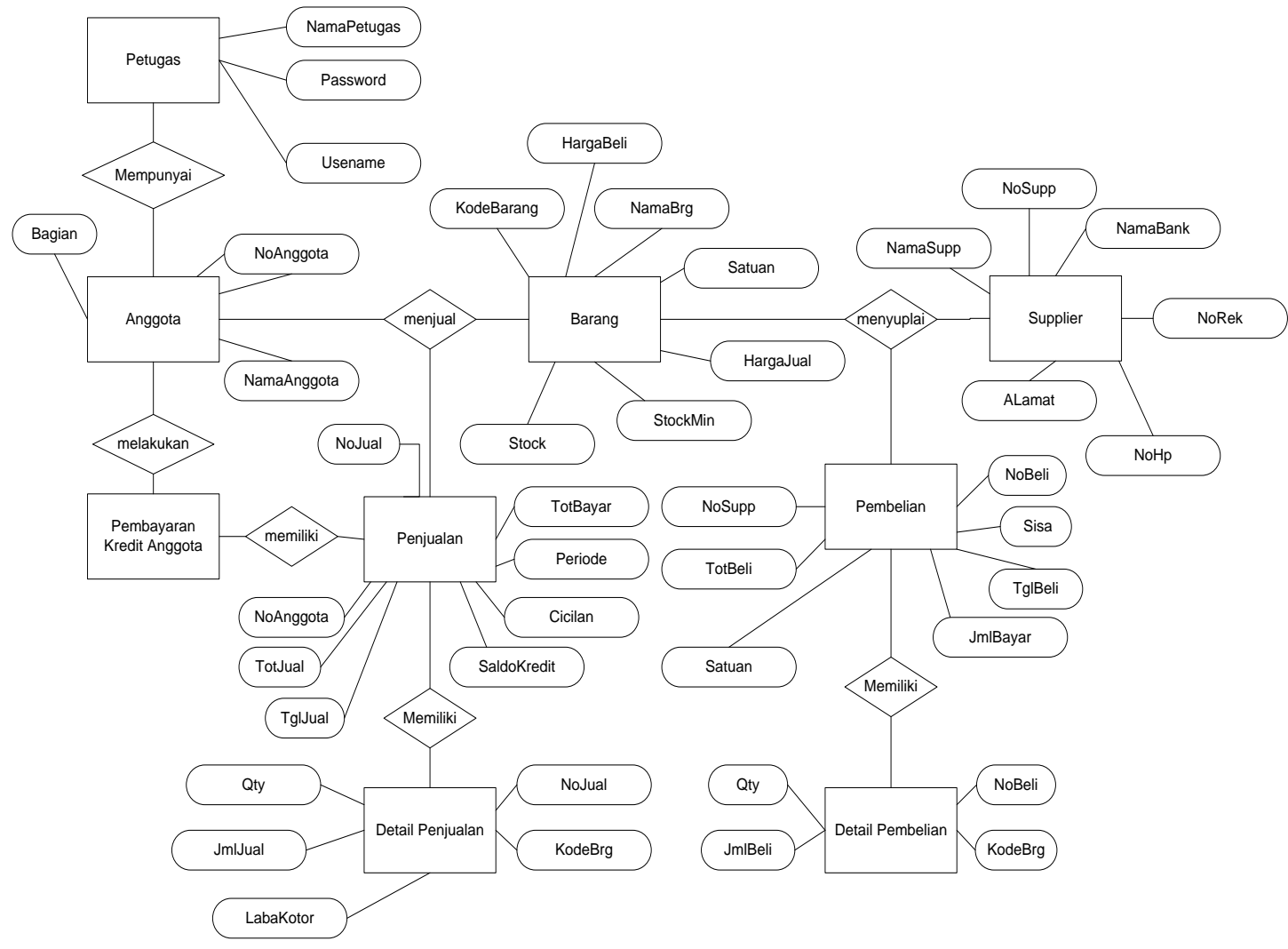

\section{Gambar 5 ERD Persediaan Barang}

\subsection{Deskripsi Tabel}

Deskripsi tabel akan dijelaskan pada tabel-tabel sebagai berikut :

1. Tabel Petugas

Nama Tabel

: Petugas

Fungsi

: Menyimpan Data Petugas

Jenis

: Master 
Primary Key : Id

Tabel 6 Data Petugas

\begin{tabular}{|c|c|l|c|l|}
\hline No & Nama Field & Type & Size & Keterangan \\
\hline 1 & Username** & $\begin{array}{l}\text { Short } \\
\text { Text }\end{array}$ & 10 & $\begin{array}{l}\text { Username } \\
\text { Petugas }\end{array}$ \\
\hline 2 & NamaPetugas & $\begin{array}{l}\text { Short } \\
\text { Text }\end{array}$ & 25 & $\begin{array}{l}\text { Nama } \\
\text { Petugas }\end{array}$ \\
\hline 3 & Password & Number & 10 & Password \\
\hline
\end{tabular}

2. Tabel Anggota

Nama Tabel : Anggota

Fungsi : Menyimpan Data Anggota

Jenis : Master

Primary Key : NoAnggota

Tabel 7 Data Anggota

\begin{tabular}{|c|l|l|l|l|}
\hline No & Nama Field & \multicolumn{1}{|c|}{ Type } & Size & Keterangan \\
\hline 1 & NoAnggota** $^{*}$ & $\begin{array}{l}\text { Short } \\
\text { Text }\end{array}$ & 20 & $\begin{array}{l}\text { Nomer } \\
\text { Anggota }\end{array}$ \\
\hline 2 & NamaAnggota & $\begin{array}{l}\text { Short } \\
\text { Text }\end{array}$ & 25 & Nama Anggota \\
\hline 3 & Bagian & $\begin{array}{l}\text { Short } \\
\text { Text }\end{array}$ & 25 & Bagian \\
\hline 4 & NoTelpon & Number & 13 & Nomer Telpon \\
\hline 5 & TglMasuk & Date & 8 & Tanggal Masuk \\
\hline 6 & Status & $\begin{array}{l}\text { Short } \\
\text { Text }\end{array}$ & 10 & Status \\
\hline
\end{tabular}

3. Tabel Barang

$\begin{array}{ll}\text { Nama Tabel } & : \text { Barang } \\ \text { Fungsi } & : \text { Menyimpan Data Barang } \\ \text { Jenis } & : \text { Master } \\ \text { Primary Key } & : \text { KodeBrg }\end{array}$

Tabel 8 Data Barang

\begin{tabular}{|c|l|c|c|l|}
\hline No & \multicolumn{1}{|c|}{ Nama Field } & Type & Size & Keterangan \\
\hline 1 & KodeBrg** & $\begin{array}{c}\text { Short } \\
\text { Text }\end{array}$ & 20 & Kode Barang \\
\hline 2 & NamaBrg & $\begin{array}{c}\text { Short } \\
\text { Text }\end{array}$ & 35 & Nama Barang \\
\hline 3 & Stock & Number & 4 & Stock \\
\hline 4 & StockMin & Number & 4 & $\begin{array}{l}\text { Stock } \\
\text { Minimum }\end{array}$ \\
\hline 5 & HargaJual & Currency & 8 & Harga Jual \\
\hline 6 & HargaBeli & Currency & 8 & Harga Beli \\
\hline 7 & Satuan & Number & 4 & Satuan \\
\hline
\end{tabular}

4. Tabel Supplier

Nama Tabel $\quad$ : Supplier 
$\begin{array}{ll}\text { Fungsi } & : \text { Menyimpan Data Supplier } \\ \text { Jenis } & \text { : Master } \\ \text { Primary Key } & \text { : NoSupp }\end{array}$

Tabel 9 Data Supplier

\begin{tabular}{|c|l|c|c|l|}
\hline No & $\begin{array}{c}\text { Nama } \\
\text { Field }\end{array}$ & Type & Size & Keterangan \\
\hline 1 & NoSupp** & Short Text & 15 & No Supplayer \\
\hline 2 & NamaSupp & Short Text & 25 & Nama Supplayer \\
\hline 3 & Alamat & Short Text & 50 & Alamat \\
\hline 4 & NoHp & Number & 13 & $\begin{array}{l}\text { Nomer } \\
\text { Handphone }\end{array}$ \\
\hline 5 & NoBank & Short Text & 4 & Nomer Bank \\
\hline 6 & NamaBank & Short Text & 35 & Nama Bank \\
\hline 7 & NoRek & Short Text & 30 & $\begin{array}{l}\text { Nomer } \\
\text { Rekening }\end{array}$ \\
\hline
\end{tabular}

5. Tabel Pembelian

Nama Tabel : Pembelian

Fungsi : Menyimpan Transaksi Pembelian

Jenis : Transaksi

Primary Key : NoBeli

Tabel 10 Data Pembelian

\begin{tabular}{|c|l|c|c|l|}
\hline No & Nama Field & Type & Size & \multicolumn{1}{|c|}{ Keterangan } \\
\hline 1 & NoBeli** & $\begin{array}{c}\text { Short } \\
\text { Text }\end{array}$ & 20 & Nomer Beli \\
\hline 2 & TglBeli & Date & 8 & Tanggal Beli \\
\hline 3 & NoSupp & $\begin{array}{c}\text { Short } \\
\text { Text }\end{array}$ & 15 & $\begin{array}{l}\text { Nomer } \\
\text { Supplayer }\end{array}$ \\
\hline 4 & TotBeli & Currency & 8 & Total Beli \\
\hline 5 & Satuan & Number & 4 & Satuan \\
\hline 6 & JmlBayar & Currency & 8 & Jumlah Bayar \\
\hline 7 & Sisa & Currency & 8 & Sisa \\
\hline
\end{tabular}

6. Tabel Detail Beli

Nama Tabel : DetailBeli

Fungsi : Menyimpan Transaksi Detail Beli

Jenis : Transaksi

Primary Key : :-

Tabel 11 Data Detail Beli

\begin{tabular}{|c|l|c|c|l|}
\hline No & $\begin{array}{c}\text { Nama } \\
\text { Field }\end{array}$ & \multicolumn{1}{|c|}{ Type } & Size & Keterangan \\
\hline 1 & NoBeli $* *$ & Short Text & 20 & Nomer Beli \\
\hline 2 & KodeBrg & Short Text & 20 & Kode Barang \\
\hline 3 & Qty & Number & 4 & Quantity \\
\hline 4 & JmlBeli & Currency & 4 & Jumlah Beli \\
\hline
\end{tabular}

7. Tabel Penjualan

Nama Tabel : Penjualan

Fungsi : Menyimpan Transaksi Penjualan 
Jenis : Transaksi

Primary Key : : NoJual

Tabel 12 Data Penjualan

\begin{tabular}{|c|l|c|c|l|}
\hline No & $\begin{array}{c}\text { Nama } \\
\text { Field }\end{array}$ & Type & Size & Keterangan \\
\hline 1 & NoJual $* *$ & Short Text & 15 & NoJual \\
\hline 2 & TglJual & Date & 8 & TglJual \\
\hline 3 & NoAnggota & Short Text & 20 & NoAnggota \\
\hline 4 & TotJual & Currency & 8 & TotJual \\
\hline 5 & TotBayar & Currency & 8 & TotBayar \\
\hline 6 & Periode & Short Text & 3 & Periode \\
\hline 7 & Cicilan & Short Text & 3 & Cicilan \\
\hline 8 & $\begin{array}{l}\text { Saldo } \\
\text { Kredit }\end{array}$ & Currency & 8 & Piutang \\
\hline
\end{tabular}

8. Tabel Detail Penjualan

Nama Tabel : DetailPenjualan

Fungsi : Menyimpan Transaksi Detail Penjualan

Jenis : Master

Primary Key : :-

Tabel 13 Data Detail Penjualan

\begin{tabular}{|c|l|c|c|l|}
\hline No & Nama Field & Type & Size & Keterangan \\
\hline 1 & NoJual** & $\begin{array}{c}\text { Short } \\
\text { Text }\end{array}$ & 15 & Nomer Jual \\
\hline 2 & KodeBrg & $\begin{array}{c}\text { Short } \\
\text { Text }\end{array}$ & 15 & Kode Barang \\
\hline 3 & Qty & Number & 4 & Quantity \\
\hline 4 & JmlJual & Number & 4 & Jumlah Jual \\
\hline 5 & LabaKotor & Currency & 8 & Laba Kotor \\
\hline
\end{tabular}

9. Tabel Pembayaran Kredit Anggota

Nama Tabel : Pembayaran Kredit

Fungsi : Menyimpan Transaksi Pembayaran Kredit

Jenis : Transaksi

Primary Key : NoJual

Tabel 14 Data Pembayaran Kredit

\begin{tabular}{|c|l|c|c|l|}
\hline No & Nama Field & Type & Size & Keterangan \\
\hline 1 & NoJual** & $\begin{array}{c}\text { Short } \\
\text { Text }\end{array}$ & 15 & Nomer Jual \\
\hline 2 & NoAnggota & $\begin{array}{c}\text { Short } \\
\text { Text }\end{array}$ & 20 & $\begin{array}{l}\text { Nomer } \\
\text { Anggota }\end{array}$ \\
\hline 3 & SaldoKredit & Currency & 8 & Saldo Piutang \\
\hline 4 & TglJatuhTempo & Date & 8 & $\begin{array}{l}\text { Tgl Jatuh } \\
\text { Tempo }\end{array}$ \\
\hline
\end{tabular}

\subsection{Structure Chart}




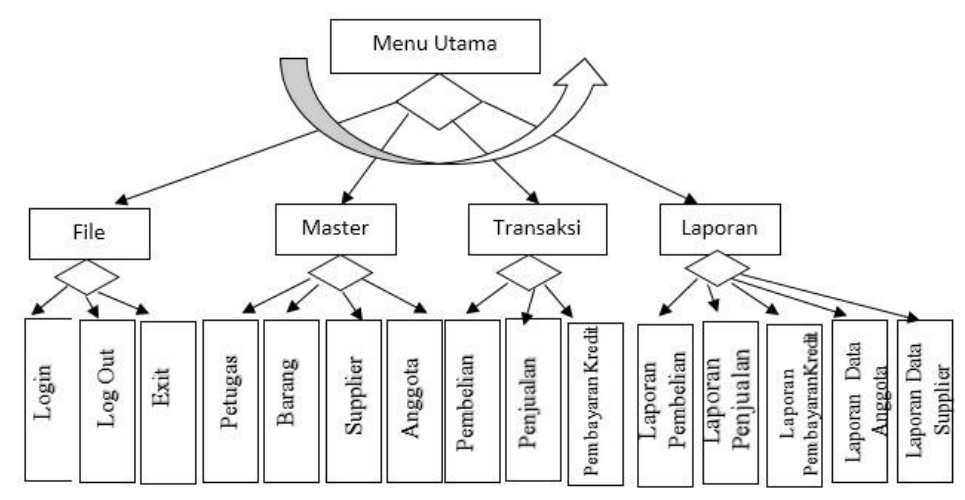

Gambar 5 Structure Chart

\section{PENUTUP}

\subsection{Kesimpulan}

Berdasarkan hasil proses perancangan sistem informasi di Koperasi Brimob Polda Jabar Jatinangor yang penulis buat, maka dapat ditarik kesimpulan bahwa:

4. Sistem aplikasi ini dapat memberikan kemudahan dalam proses pembelianbarang dan penjualan barang, dan pembayaran kredit.

5. Sistem dapat memberikan kemudahan dalam mengontrolpenjualan dan pembelian serta stok barang secara realtime.

6. Dengan adanya sistem ini dapat memberikan kemudahanmerekap penjualan dan pembelian setiap hari.

7. Dengan adanya sistem ini dapat memberikan kemudahan pembuatan laporan.

8. Dapat memudahkan membuat laporan pembayaran kredit anggota menjadi mudah secara otomatis.

\subsection{Saran}

Berdasarkan kepada kesimpulan yang telah dibuat pada penelitian ini, mak penulis merekomendasikan beberapa saran yang dapat menjadi acuan untuk pengembangan selajutnya, diantaranya yaitu:

1. Untuk meningkatkan kecepatan dan efisiensi serta kepuasan anggota koperasi dalam transaksi penjualan dan pembelian maka diperlukan sistem berbasis online.

2. Pelaporan dan notifikasi untuk cicilan kredit anggota perlu ditambahkan dalam menanggulangi kekhilapan pada anggota dalam membayar cicilan kredit dengan berupa sms gateway ataupun aplikasi reminder berbasis realtime dan online.

3. Penelitian ini belum sepenuhnya komprehensif, karena hanya melihat dari fungsional tanpa melihat performansi sistem, sehingga diperlukan peningkatan performansi sistem dalam bentuk keamanan sistem yang lebih bagus dengan metode enkripsi dan dan teknologi server standar pada infrastukturnya.

\section{DAFTAR PUSTAKA}

AMIK Al Ma'soem. (2017). Panduan Penyusunan Tugas Akhir. Bandung ： AMIK Al Ma'soem.

Nazir, Mohamad. (2013). Metode Penelitian. Bogor: Ghalia Indonesia.

Sugiyono. (2013). Metode Penelitian Kuantitatif, Kualitatif dan R\&D. Bandung: Alfabeta.CV 
Diana, Anastasia dan Setiawati, Lilis. (2011). Sistem Informasi Akuntansi Perancangan, Proses dan Penerapan. Yogyakarta: Andi.

Jogiyanto, H.M. (2005). Analisa dan Desain Sistem Informasi.Yogyakarta: Andi Offset.

Jogiyanto, H.M. (2014). Analisa dan Desain Sistem Informasi. Yogyakarta: Andi Offset.

Kusrini. (2007). Strategi Perancangan Dan Pengelolaan Basis Data. Yogyakarta: Andi

Brady, M., \& Loonam, J. (2010). Exploring the use of entitiy-relationship diagramming as a technique to support grounded theory inquiry. Bradford: Emerald Group.

Leitch, Robert.A dan Davis, K. Roscoe. (2014). Analisa dan Desain Sistem Informasi Yogyakarta : Andi Offset. 